\title{
The Role of the Forensic Accountant in the Detection of Tax Fraud in Financial Statements: A Survey Study in the Jordanian Accounting and Auditing Offices and Firms
}

\author{
Ola Mohammad Khersiat ${ }^{1}$ \\ ${ }^{1}$ Accounting Department, Faculty of Economics and Administration Sciences, Zarqa University, Jordan \\ Correspondence: Ola Mohammad Khersiat, Accounting Department, Zarqa University, P.O. Box 132222, Zarqa \\ 13110, Jordan. Tel: 962-779-069-109. E-mail: ola_khresiat_1978@yahoo.com
}

Received: February 27, 2018

Accepted: March 30, 2018

Online Published: April 10, 2018

doi:10.5539/ijef.v10n5p145

URL: https://doi.org/10.5539/ijef.v10n5p145

\begin{abstract}
This study aims to emphasize the need for a forensic accountant to detect the manipulation of financial statements and combat tax fraud, and to identify the tax fraud-detecting means used by the forensic accountant in Jordan. To this end, the researcher prepared a questionnaire which was distributed among 125 forensic accountants working in Jordanian accounting and auditing firms. After analyzing and testing the hypotheses using SPSS, the following outcomes were drawn: The forensic accountant has the qualifications, expertise and skills to detect tax fraud in financial statements as well as detect the manipulation of financial statements figures.
\end{abstract}

Keywords: forensic accountant, fraud, tax, financial statements

\section{Introduction}

Modern accounting scandals have caused companies to increase legal and regulatory requirements to improve corporate leadership and control, especially as economic activities are clever in concealing those scams and accounting tricks. Some companies use creative accounting techniques to mask and conceal dangerous information, distort the financial health of economic activity, mitigate the disturbance of revenues or uplift the imaginary payment of small revenues (Lopez, 2003). In accordance with legal requirements, we believe that the priority lies in the ability of internal controls to detect fraud and thus increase the demand for experts with knowledge and skills on fraud and forensic accounting.

A forensic accountant's main task is to detect financial fraud in financial statements as they objectively and appropriately conduct an in-depth examination of fraudulent activities in order to come up with a powerful tool that can detect fraud and manipulation in financial statements.

The forensic accountant uses the techniques of tax officers in calculating the income, expenses and net value to prove the existence of non-disclosed income and thus the existence of a fraud element by referring to specific income items not shown in the tax declaration. The taxpayer may delete sales, large transactions or shares-selling activities. Under direct methods, tax officers use traditional techniques such as searching for canceled or paid checks, real estate transaction documents, public records, and other direct evidence of undeclared or unreported income (Meldman et al., 2001).

Forensic accounting has proven to be an effective weapon in the fight against financial crimes in developed countries. Statements recently released by the Director of the Department of Income and Sales during the dialogue session held by the Transparency International have shown that the value of tax evasion for 2016 amounted to about 1.5 JD billion while the value of collected tax revenues reached 3.828 billion dinars for the same year.

As most studies have pointed out, the reasons for tax evasion are due to citizens perception that the tax rate is very high compared to profits, and that the service provided to companies is not entitled to all these taxes.

Hence, this study highlights the role of the forensic accountant in detecting tax fraud in the financial statements in Jordan, where the collection of taxes and fees covers $90 \%$ of the budget and the government covers the deficit through grants and bonds (http://assabeel.net/news/4947/2017/3/19). 


\section{Literature Review}

Akkeren et al. (2014) points out to the fact that the multidisciplinary nature of forensic accounting in Australia has created significant challenges in ensuring appropriate regulatory governance structures are in place. For the most part practitioners in this field are co-regulated through professional accounting bodies and under affiliate statutory provisions. As Australia lacks regulatory provisions for accountants not within this framework, however, those operating outside this umbrella are subject only to broader catch all legislation such as consumer protection provisions and specialized expert witness requirements. Globalization and outsourcing of key services in this context further complicates ensuring effective consumer protection touchstones are in place. Debate on whether - and how - to formalize this framework is active and contentious. In part this is due to the rapid expansion of this field and the flow on effects it has; in part it joins broader debate regarding national regulation of Australia's professions generally and the country's broader competition policy objectives. Given domestic and international concern over ensuring high quality service provision in the emerging forensic accounting discipline, this issue is likely to be of mounting concern in the next several years. The paper sets out Australia's regulatory background and the context against which such changes must be formulated, issues and tensions that are emerging in this space and, in conclusion, recommendations as to potential directions forward.

Eliezer et al. (2015), ALMusalam et al. (2015), Enofe et al. (2015), Adebisi et al. (2016), The explore the role of forensic accountants in fraud investigation and the knowledge and skills forensic accountants are expected to possess and differences between a forensic accountant and traditional accountant. Eliezer et al. (2015) emphasizes that the increase in the number of cases of financial fraud due to failure of statutory audit to detect and prevent fraudulent activities has given rise for the services of forensic accountants. The paper highlights how forensic accountants can be employed to resolve this challenge. The study was a theoretical research which considered the roles of forensic accountants in combating fraudulent activities, differences between a forensic accountant and traditional accountant, features of a forensic accountant and the impact of forensic accountants to detect and prevent fraud. From the research, it was found out among to theirs that their services will assist audit committee members in carrying out their oversight functions by providing them assurance on internal audit report. Some of their commendations proffered is for government to ameliorate the cost of hiring the services of forensic accountants and to treat culprits equally without any favoritism.

ALMusalam et al. (2015) the study explains the role of forensic accounting in fraud investigation in view of accounting professionals, financial analysts and auditors in Bahrain. The result showed that forensic accountant is important in fraud investigation and curb and resolve economic and financial crimes in Bahrain economy. The researchers recommend among others that the government of Bahrain Should enact an act that will make forensic accounting a practice in Bahrain so that economic and financial crimes can become history.

Enofe et al. (2015) considers that the broad objective of their study is to examine the role of forensic accounting in curbing financial crimes. The study adopts a survey research design. The method was adopted because it is likely to generate the kind of information required as well as providing good basis for the generalization of findings. The population of the study comprises of staffs of selected banks. Primary data was used for the purpose of this research. This research work employed the use of structured questionnaire in eliciting the required data needed to test the formulated hypotheses. Regression analysis was utilized as the method of data analysis and the results will be used in testing the hypotheses specified in the study. The study finding reveals that there is a need for forensic accountants in the Nigerian banking system. Forensic accounting is an effective tool for addressing financial crimes in the banking system and finally that conventional accounting techniques are not effective in curbing financial crimes. The recommendation is that there is the need for corporations in Nigeria to engage the services of forensic accountants as forensic accounting now appears as a one of the strategic and dynamic tool for the management of all types of financial crimes. Also, they need to focus on training and up-dating the skills of the internal control and audit staffs.

Adebisi et al. (2016) aims, through their study, at investigating how forensic accounting has abetted the detection and prevention of fraud in Nigeria. The study is a survey research which used primary data collected with the aid of questionnaire administered to 92 sampled professional accountants in Nigerian public sector. The data collected was analyzed using chi-square. The findings of the study suggest that forensic accounting has a significant role to play in fraud detection and prevention in Nigeria. The researchers therefore, recommend that there should be more forensic accountant's involvement in fraud detection in order to reduce the rate of financial crime in Nigeria

Likewise, Alkubais (2016) aimed, through his study, to realize an empirical investigation about the status of forensic accounting in resolving the disputes of a financial nature in Jordan, depending up on judicial and 
forensic accountant`s point of view. The study used a descriptive analytical approach for the presentation and analysis of data, relying mainly on a questionnaire designed especially for this purpose. The most important findings reveal that the status or importance of forensic accounting, availability of data, and qualifications of forensic accountant were $85 \%, 80 \%$, and $80 \%$ respectively according to the judicial point of view, while from the forensic accountant`s point of view were respectively $74 \%, 70 \%$, and $81 \%$.On the light of these results, and by comparison with the real role of forensic accounting in the assurance of justice and fraud confrontation, the most important conclusion indicates the in sufficient level of that situation. Then many recommendations were proposed to improve the status of forensic accounting in Jordan.

Domino et al. (2017) presents a study in which results ranked the certifications using the opinions of two groups of experts: attorneys and academics. A significant amount of the attorney experts' practices dealt with forensic support services and the academic experts teach and/or are engaged in forensic accounting. Results show three certifications perceived to be of most value to accountants for forensic support services by both the attorney and academic experts: Certified in Financial Forensics (CFF), Certified Forensic Accountant (CRFAC), and Accredited in Business Valuation (ABV). The results are interesting, particularly since the Certified Fraud Examiner (CFE) is listed as one of the most marketable credentials available by Robert Half (2015). Attorney experts ranked the CFE fifth as to perceived value, while the academic experts ranked the CFE fourth.

Additionally, the AICPA sponsors both the ABV and the CFF certifications, and they require applicants to meet education and experience requirements as well as be licensed as a CPA. Holders of the CFE must meet similar requirements, but they are not required to be licensed CPAs.

The attorney experts ranked having a CPA license higher than did the academic experts. This difference may be related to the fact that CPAs appear to be preferred by attorneys as expert witnesses. Apparently, attorneys view a CPA designation as a very important credential. Education was also very important to both groups which are implicit to having a CPA designation. Surprisingly, having neither a code of ethics nor a certification with specificity in forensics appeared to significantly impact the final rankings of the certifications. This result may reflect the fact that CPAs are guided by the AICPA Code of Ethics.

The findings are also interesting since the researchers contacted several companies which hire forensic accountants. In most instances, both law and accounting firms identified the CFE certificate as a very valuable forensic certification. In other situations, no preference was identified as to a particular forensic certification.

The ranking of the perceived value of the Certified Information Systems Auditor (CISA) is also of interest. This ranking makes sense, as technology and the use of data analytics is of great importance to understanding information of firms. This finding suggests that greater focus be placed on information technology and its related use in training forensic accountants, such as in data analytics and related software applications.

\section{Theoretical Framework}

The researcher defines tax evasion as a set of acts and actions illegally carried out by the taxpayer, considered to be intentionally violating the law to reduce the tax amount or evade paying the tax due.

The taxpayer accused of fraud and tax evasion has voluntarily committed many acts against the law. Tax evasion differs from planning or tax avoidance, in which the taxpayer regulates his income sources in a legal way making him non-taxable or reducing the amount of tax due (Hopwood et al., 2008, p. 320).

In this case, the role of the forensic accountant is to check and search for fraud and manipulation of financial reports and lists in order to detect tax fraud. The forensic accountant often conducts his investigations by interviewing the taxpayer, visiting work sites, evaluating internal controls and analyzing ratios as well as the financial situation of the taxpayer to estimate the income not disclosed in the tax declaration of these companies. The forensic accountant must observe the taxpayer`s lifestyle and determine their standard of living since the obvious changes in the taxpayer's lifestyle indicate fraud and non-disclosed income.

There are two ways to determine the taxpayer's income, either directly or by specific items based on the collection of original documents and records of the taxpayer and the direct income index, preferred by the Income and Sales Tax Department in Jordan. (Price et al., 1998) has shown that the direct way would be by visiting the government offices to obtain proof of real estate transactions. Checking invoices sent to senior customers can also show the undeclared sales in the tax declaration (Price et al., 1998).

The indirect method of determining the income shall be used when the taxpayer does not have sufficient accounting records and books that reflect taxable income .In this case, the taxpayer is believed to have deleted taxable income. 
The embezzlement investigation techniques consist of two approaches; preventive and the rapeutic. The preventive approach includes the following:.

Effective and powerful internal controls.

- Financial and operational audits.

- Intelligence work in collecting information.

- Registering exceptions.

- Reviewing deviations.

On the other hand, the therapeutic approach includes:

Investigation of complaints and allegations Intuition Suspicion and uncertainty (Bologna et al., 1995).

There are four indirect methods to detect non-disclosed income. These are: calculating funds, expenditure (sources and uses of funds), the net worth method and the bank deposits. These methods show that the estimated income of the taxpayer is higher than the income declared in the tax declaration (Crumbley et al., 2007, pp. 6-7).

1- The funds method (Funds T)

It is an analysis of the total funds received and the total funds spent by the taxpayer in a specific period of time. In case the taxpayer's expenses exceed the income stipulated in their tax statement and there is no justification from their part regarding the source of fund used to pay for such expenses, such increase represents non-disclosed income (Hopwood et al., 2008, p. 352).

\section{2- Net worth Method}

That the net worth method is considered appropriate for any taxpayer when two or more years have been audited and for which a tax declaration has been presented to tax authorities by the tax officer who observes significant changes in assets and liabilities from one year to another (Crumbley et al., 2007, pp. 6-17).

3- Source and Application of Funds Method $\backslash$ Expenditure Approach

This method consists of a list of funds uses at the beginning of the period, subtracting the sources of funds. If the actual sources of funds exceed the declared ones (including the balance of the funds store at the beginning of the period), the difference is considered non-disclosed income.

Applying both methods: Source and Application of Funds- Funds Calculation is appropriate for the tax payer who does not deposit the significant portion of his income into his bank accounts or in case his expenses included in the tax statement do not match with his non-disclosed income (Crumbley et al., 2007, pp. 6-17).

4- The bank deposits method

This method focuses on the funds deposited during the year from unknown sources through checking bank records and financial transactions. The following formula is used to calculate this method:

Total deposits in all accounts (referring to the total deposits shown on the deposit voucher minus the received funds)

Minus (transfers between accounts + withdrawals and re-deposits)

Equals net deposits in all accounts (total deposits shown on deposit voucher minus received funds)

Minus non-taxable deposited funds equals net deposits of taxable funds

The funds stock increase is added

Funds expenditure is added (amounts paid by the taxpayer during the year under investigation minus net bank distributions. The net bank distributions shall be calculated as follows: net deposits in all accounts + beginning of period balances $=$ total available funds - end of period balances $=$ net bank distributions, being the largest amount possible to be paid in check by the taxpayer)

Equals the total of net deposits and expenses paid and funds accumulated from all sources

Minus non-taxable funds paid to: expenses, capital items and funds accumulation

Equals the total amount of funds received from all taxable sources

Subtracting funds from known sources (including salaries, inheritance, loans, income from economic activity)

Equals funds from unknown sources (Hopwood et al., 2008, pp. 346-348).

There are other indirect methods used by the forensic accountant as follows: 
1- Profit margin method: This method is preferred when the money received is not deposited and when it is not possible to determine the total paid cash expenses - unless disclosed by the relevant taxpayer (Hopwood et al., p. 346).

2- The unit and volume method: In this method the unit sale price is multiplied by the total units sold. The total sold units is determined either by referring to the main suppliers of the taxpayer or from the calculation of the cost of sold goods. This method is used when the economic activity subject to investigation produces a large number of ordinary and similar products (unprocessed according to customer specification) (Hopwood et al., 2008, p. 348).

3- Ratios analysis: That statistical analyses and ratios analyses are not a test of the reliability of expenditure figures and declared income, and do not substitute for the income test as a step in the audit process. Rather, statistical and ratios analyses are used to indicate the preference for additional tests. The forensic accountant needs to conduct audit tests to determine the reliability of the taxpayer`s accounting records and books, as well as apply direct and indirect methods to determine the total profit (Crumbley et al., 2007, pp. 6-23).

\section{Research Methodology}

The field study aims to clarify the role of the forensic accountant in detecting tax fraud in the financial statements. To achieve this end, the researcher has prepared a questionnaire based on the Likert-type scale consisting of five-level items (strongly agree, agree, neutral, disagree, and strongly disagree). The ordinals (1, 2 , $3,4,5)$ were given respectively.

The statistical methods were used through the SPSS program to analyze and test the hypotheses of the study, and to analyze the trends of differences in the views of the study sample. The arithmetical mean and the standard deviation were used to survey the views of the study sample regarding the questions prepared by the researcher. The One Sample T-Test was used to test hypotheses and survey the views of forensic accountants on each hypothesis mentioned in the study.

\subsection{The Study Sample}

The study sample consists of forensic accountants working in accounting and auditing firms. 140 questionnaires were distributed, of which 125 were received and regarded acceptable for the purposes of this study.

\subsection{Characteristics of the Study Sample}

To determine the characteristics of the study sample, in this case, criminal accountants, the data indicate that the respondents' job positions(accountant, financial manager, auditor, audit manager assistant, and audit manager) had the following ratios for each $(0.08,0.04,0.52,0.32,0.04)$. The questionnaire included the respondents' experience as follows: less than 5 years with a ratio of (0.376), 5-10 years with a ratio of $(0.48)$, and 10-15 years with a ratio of (0.08) more than 15 years with a ration of (0.064). The respondents` academic qualifications were also included in the questionnaire. B.A. degree reached a ration of (0.68), M.A. (0.24), and $\mathrm{PhD}(0.08)$. Regarding specialties, the majority were accountants with a ration of $(100 \%)$, whereas the other ones reached $(0)$ as shown in Table 1. In general, these data indicate the eligibility of the sample in providing appropriate answers to the study questions.

Table 1. Characteristics of the study sample

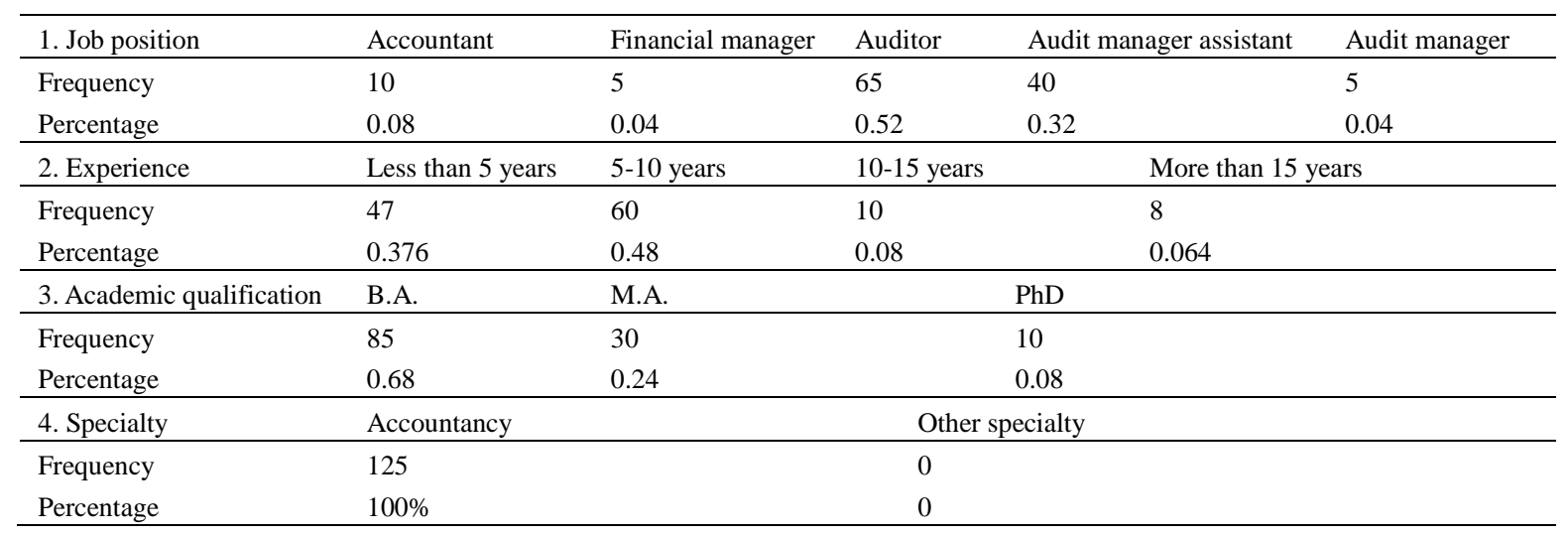




\subsection{Internal Consistency among Scales}

The Cronbach Alpha coefficient was used to measure the internal consistency among scales. The value of the Cronbach alpha coefficient among all the items of the first questionnaire reached $(82.3 \%)$, and $(81.1 \%)$ of the second. This value is considered high and reflects sufficient stability values to conduct this study since the acceptable percentage of significance to indicate the stability of the study tools is $(60 \%)$.

\subsection{Results Analysis and Hypothesis Testing}

The responses on the role of the forensic accountant in detecting tax fraud in financial statements were analyzed to obtain the study sample views regarding the following hypotheses:

1). The forensic accountant lacks the qualifications, experience and skills to detect tax fraud.

2). The forensic accountant is not capable of detecting the manipulation of figures in the financial statements

The following table shows the descriptive statistics (arithmetic mean, standard deviation) for each item of this questionnaire.

Table 2. One-sample statistics

\begin{tabular}{lcccc}
\hline & $\mathrm{N}$ & Mean & Std. Deviation & Std. Error Mean \\
\hline $\begin{array}{l}\text { - The forensic accountant uses investigative techniques that } \\
\text { fall outside the scope of traditional financial auditing }\end{array}$ & 125 & 4.9920 & .08944 & .00800 \\
$\begin{array}{l}\text { - The forensic accountant is appointed to have an independent } \\
\text { view and understanding of regulations and rules, persons and }\end{array}$ & 125 & 4.7360 & .44257 & .03958 \\
$\begin{array}{l}\text { data to detect fraud in financial statements and reports. } \\
\text { Average }\end{array}$ & 12 & 4.9140 & .07269 & .02098 \\
\hline
\end{tabular}

Table 2 shows that the item "The forensic accountant uses investigative techniques that fall outside the scope of traditional financial auditing" ranked first in the measurement items achieving an average of (4.9920) and a standard deviation of (0.8944). On the other hand, the item "The forensic accountant is appointed to have an independent view and understanding of the controls and regulations, persons and data, in order to detect fraud in financial reports and statements."Ranked last among items with an arithmetic mean of (4.7360) and a standard deviation of (.44257). Results indicate that the arithmetic mean to all items reached (4.9140) which is a strong indicator that the forensic accountant has the qualifications, expertise and skills to detect tax fraud.

Table 3. One-sample statistics

\begin{tabular}{|c|c|c|c|c|}
\hline & $\mathrm{N}$ & Mean & Std. Deviation & Std. Error Mean \\
\hline $\begin{array}{l}\text { - The forensic accountant uses the direct method, which includes the search } \\
\text { for the undeclared income by referring to specific items that are not shown in } \\
\text { the tax declaration and which are based on the direct income index, relying } \\
\text { on collecting evidence, documents and original documents rather than }\end{array}$ & 125 & 4.9040 & .29578 & .02646 \\
\hline $\begin{array}{l}\text { - The forensic accountant determines the total units sold from the calculation } \\
\text { of the cost of goods sold or by referring to the main suppliers of the } \\
\text { taxpayer-The forensic accountant uses the operational ratios analysis when } \\
\text { checking on the economic activities of companies. }\end{array}$ & 125 & 4.2240 & .41860 & .03744 \\
\hline Average & 14 & 4.6703 & .20651 & .05519 \\
\hline
\end{tabular}

Table 3 shows that the item "The forensic accountant uses the direct method, which includes the search for undeclared income by referring to specific items that are not shown in the tax declaration and based on the direct income index, relying on collecting evidence, documents and original documents rather than on indirect estimates ranked first with an arithmetic mean of (4.9040) and a standard deviation of (299578), whereas the item "The forensic accountant determines the total units sold from the calculation of the cost of goods sold or by referring to the main suppliers of the taxpayer" and the item "The forensic accountant uses the operational ratios analysis when checking on the economic activities of companies" ranked last among items with an arithmetic mean of (4.2240), and a standard deviation of (41860). Results show that the arithmetic mean for all items reached (4.6703) which is considered a strong indicator that the forensic accountant is capable of detecting the manipulation of figures in the financial statements. 


\subsection{Testing Hypotheses}

The researcher has used the One-Sample Test to test the current study hypotheses at the Confidence Interval of the Difference of $95 \%$. The results of the hypotheses test are as follows:

\subsubsection{Test results of the First Hypothesis}

The first hypothesis is that "the forensic accountant lacks the qualifications, expertise and skills to detect the tax fraud." To test this hypothesis, One-Sample Test was used for a single sample using Test Value $=3$ as a reference value representing the Likert average. Table 4 shows the results of this test:

Table 4. One-sample T test

\begin{tabular}{cccccc}
\hline & \multicolumn{5}{c}{ Test Value=3 } \\
\hline & & & Mean & \multicolumn{2}{c}{ 95\% Confidence Interval of the Difference } \\
\cline { 5 - 6 } $\mathrm{T}$ & Df. & Sig. (2-tailed) & Difference & Lower & Upper \\
\hline 91.209 & 11 & .000 & 1.91400 & 1.8678 & 1.9602 \\
\hline
\end{tabular}

The table above shows that siq $=0.00$ is less than $(0.05)$, indicating the significance of the difference between the arithmetic mean of the sample adopted according to the measuring tool (3) meaning that the forensic accountant has the qualifications, expertise and skills to detect the tax fraud in the financial statements. Eventually, this refutes the null hypothesis that "The forensic accountant lacks the qualifications, expertise and skills to detect tax fraud in the financial statements."

\subsubsection{Test results of the Second Hypothesis}

The second hypothesis is that "A forensic accountant is not capable of detecting the manipulation of figures in the financial statements." To test this hypothesis, One-Sample Test was used for a single sample using Test Value $=3$ as a reference value. Table 5 below shows the results of this test:

Table 5. One-sample T test

\begin{tabular}{cccccc}
\hline \multicolumn{7}{c}{ Test Value $=3$} \\
\hline & & & \multicolumn{2}{c}{ 95\% Confidence Interval of the Difference } \\
\cline { 5 - 6 } T & Df & Sig. (2-tailed) & Mean Difference & Lower & Upper \\
\hline 30.263 & 13 & .000 & 1.67029 & 1.5511 & 1.7895 \\
\hline
\end{tabular}

The table above shows that siq $=0.00$ is less than $(0.05)$ indicating the significance of the difference between the arithmetic mean of the sample adopted according to the measuring tool (3), namely that the forensic accountant is capable of detecting the manipulation of figures in the financial statements and thus refuting the null hypothesis stating that "The forensic accountant is not capable of detecting the manipulation of figures in the financial statements. "

\section{Conclusions and Recommendations}

\subsection{Conclusions}

1) Results show that the forensic accountant uses investigative techniques and necessary analytical skills objectively and appropriately in order to have a powerful tool that can detect fraud and manipulation of financial statements in companies that misinform on revenues, delay reporting on revenues, reduce and misappropriate the values of assets, manipulate estimates of reserves and other fraudulent methods.

2) Results indicate that a forensic accountant with a completely independent attitude is required for detecting fraud in the financial statements and conducting research that would lead to significant deviations in the financial statements.

3) Results show that the forensic accountant develops the scope of his research and queries based on the inputs coming from different sources.

4) The field study shows that the forensic accountant has a role in detecting tax fraud in the financial statements based on table 4 , which shows that siq $=0.00$ is less than (0.05). This indicates the significance of the difference between the arithmetic mean of the sample approved according to the measuring tool (3) in the sense that the forensic accountant has the qualifications, expertise and skills to detect tax fraud.

5) The field study also reveals that the forensic accountant is capable of detecting the manipulation of figures in 
the financial statements, showing that $\mathrm{siq}=0.00$ is less than (0.05), indicating the significance of the difference between the arithmetic mean of the sample approved according to the measuring tool (3), namely that a forensic accountant is capable of detecting the manipulation of figures in the financial statements.

\subsection{Recommendations}

1) Giving more consideration to forensic accounting in the Arab world in general and in Jordan in particular, since the Jordanian curricula does not provide much information on the regard. Modifying and improving an integrated curriculum in Jordanian universities that serves this specialization is of much importance.

2) Forensic accounting is a must because it provides a diagnosis of the reality of financial operations and the ability to conduct an investigation and unveil the reliability of the information contained in the financial statements.

3) The need to create new and solid legislation and regulations, and issuing laws that regulate forensic accounting to strengthen the process of governance and control of companies, in addition to creating a new type of supervision and formulating new standards to combat fraud in financial statements.

4) The presence of a forensic accountant at the Income Tax Department in order to preserve the country's financial resources, since tax has a direct impact on people and communities and touches their basic needs.

5) The need to conduct research activities in forensic accounting in the Arab world in general, and in Jordan in particular. The available researches on the regard are very few due to the fact that the concept of forensic accounting is still blurring too many.

\section{References}

Adebisi, J., \& Matthew, O. (2016). The Impact of Forensic Accounting in Fraud Detection and Prevention: Evidence from Nigerian Public Sector. International Journal of Business Marketing and Management, 1(5), $34-41$.

AI Musalam, L., \& Kukreja, G. (2015). The Role of Forensic Accounting in Fraud Investigations:A Survey Based Research from Kingdom of Bahrain. Journal of Business Management and Information Systems, 2(1).

Akkeren, J., \& Tarr, J. (2014). Regulation, Compliance and the Australian Forensic Accounting Profession. Journal of Forensic \& Investigative Accounting, 6(3).

Alkubaisi, A. (2016). An Empirical Investigation of the Forensic Accounting from Judicial and Forensic Accountant Point of View in Jordan. Jordan Journal of Business Administration, 12(1).

Bologna, G. J., \& Lindquist, R. J. (1995). Fraud Auditing and Forensic Accounting (2nd ed.). New York: John Wiley.

Crumbley, D. L., Heitger, L. E., \& Smith, G. S. (2007). Forensic and Investigative Accounting. Chicago: CCH Incorporated.

Domino, M., Giordano, G., \& Webinger., M, \& Webinger, M. (2017). An Investigation of the Factors that Impact the Perceived Value of Forensic Accounting Certifications. Journal of Forensic \& Investigative Accounting, 9(1).

Eliezer, O., \& Emmanuel, B. (2015). Relevance of Forensic Accounting in the Detection and Prevention of Fraud in Nigeria. Historical Research, 23.

Enofe, A., \& Utomwen, A. (2015). The Role of of Forensic Accounting in Mitigating Financial Crimes. International Journal of Advanced Academic Research - Social Sciences and Education.

Hopwood, W. S., Leiner, J. J., \& Young, G. R. (2008). Forensic Accounting (1st ed.). NY: McGraw Hill companies, Inc.

IRS Digital Daily. (2012). Criminal Investigation (CI) Special Agents are a Part of a "Bigger Law EnforcementTeam. Retrieved from http://www.irs.gov/irs/article/0..id=107041.00html

Lopez, L. (2003). Forensic Accounting Uncovers Teachers Union Scandal. FOX News Channel. Retrieved from http://www.Foxnews.com/story/0.2933,8560,00.htm

Meldman, R. E., \& Sideman, R. J. (2001). Fedral Taxation :Practice and Procdure (6th ed.). Chicago: CCH Incorporated.

Postal Service and General Government. (1996). Statement of IRS Assistant Commissioner for Criminal 
Investigation Donald K. Vogel Before the House Subcommittee on Treasury.

Price, C., \& Weld, L. (1998). Income Reconstruction. The CPA Journal (August1998).

Transparency International. (2017). The value of tax evasion for 2016 amounted to about 1.5 JD billion (2017). Retrieved from http://asabeel.net/news/4947/19/3/2017

\section{Copyrights}

Copyright for this article is retained by the author(s), with first publication rights granted to the journal.

This is an open-access article distributed under the terms and conditions of the Creative Commons Attribution license (http://creativecommons.org/licenses/by/4.0/). 